\title{
O CORPO NO POEMA E 0 POEMA E SEU CORPO NA LITERATURA DE AUTORIA FEMININA: UM EXEMPLO EM CECILIA MEIRELES
}

\author{
THE BODY IN THE POEM, AND THE POEM AND ITS BODY IN THE \\ LITERATURE OF FEMALE AUTHORSHP. AN EXAMPLE IN CECÍLIA MEIRELES
}

\section{RESUMO}

A poesia de Cecília Meireles foi considerada pela crítica tradicional uma poesia sem corpo, etérea e alienada das relações sociais e políticas, isto é, sem a presença do eu e alheia ao presente. Contudo, a análise de algumas obras e poemas de Meireles, tendo em vista a busca tanto do seu corpo autoral quanto do feminino, revelam uma poesia tecida com gestos e sons transfigurados em natureza. Ao mesmo tempo, a chamada eteriedade da poeta carioca esconde um corpo fluido, o qual as vezes precisa ser negado para se fazer presente e existente, enquanto sua tessitura poética será uma forma de resistência ao patriarcado que monopolizou a palavra escrita e falada, deixando para a mulher o silêncio como habitação. Neste artigo, a tessitura do corpo no tecido do texto será mostrada na poesia de Cecília Meireles como forma de resistência e existência significativa do que é ser mulher e poeta.

Palavras-chave: Autoria Feminina, Corpo, Poesia, Mulher, Cecília Meireles.

\begin{abstract}
The poetry of Cecilia Meireles was considered by traditional critics a poetry without body, ethereal and alienated from social and political relations, that is, without the presence of the self, being alien to the present. However, the analysis of some works and poems by Meireles, in search of both her authorial body and the feminine body, reveals a poetry woven with gestures and sounds transfigured in nature. At the same time, the so-called Carioca poet's ethereal characteristic hides a fluid body, which sometimes needs to be denied to be make present and existing, while its poetic texture will be a form of resistance to the patriarchy that monopolized the written and spoken word, leaving to the woman the silence as a dwelling. In this article, the texture of the body in the fabric of the text will be shown in the poetry of Cecilia Meireles as a form of resistance and significant existence of what it is to be a woman and a poet.
\end{abstract}

Keywords: Female Authorship, Body, Poetry, Woman, Cecília Meireles.

Adrienne K. S. Morelato

UNESP. Email: adriennekatiadidi@bol.com.br 
O sujeito -o eu- existe somente encarnado; nenhuma distância pode se constituir entre ele e seu corpo. Todavia o corpo transcende o eu a toda hora no -ou pelo-sono, na fadiga, na possessão, no êxtase, na morte. Ele será futuramente, um cadáver. (CORBAIN, 2005, p.8)

O corpo na poesia se expressa no corpo do poema. Há um corpo de quem escreve e de quem lê intermediado por um papel ou tela que tem também o seu corpo, e neste inscrito, o texto com toda sua materialidade. O corpo é a matéria, o texto também.

Quando se fala ou pensa em um texto escrito por mulher, se pensa em corpo de mulher. É possível imaginar por trás da letra, cabelos compridos, mãos pequenas segurando a caneta ou o lápis, quadris largos, útero, vagina. Dificilmente quando temos um texto de autora, não realçamos o fato de ser ela, pois historicamente, o corpo feminino estava alijado da condição do mundo quem dirá da escrita. A diferença anatômica entre homens e mulheres se tornou o fator de interiorização das últimas pela ligação, historicamente construída pelo patriarcado, de suas funções biológicas com a natureza.

No instante em que a humanidade começou a se afastar da natureza, através da criação de uma sociedade artificial, iniciou-se o binarismo filosófico: natureza/ cultura, corpo/mente - grandes responsáveis pela opressão das mulheres, já que, esses dualismos foram postos em posição hierárquica. Tanto é que:

Para Platão, o corpo é uma traição da alma, da razão e da mente que são aprisionadas pela materialidade corporal. Aristóteles distingue, também a matéria da forma, distinção que será depois reconfigurada pela tradição cristã, onde a separação mente / corpo foi correlacionada à distinção entre o que é imortal e o que é mortal (...) Para o cristianismo, fica bem clara a distinção entre uma alma dada por Deus, e uma matéria pecaminosa e lasciva. (XAVIER, 2007 p.17)

Tentou-se configurar essa dualidade, construída dentro do discurso, e transformada em níveis superior e inferior, como verdade universal, relacionando o homem e a mulher com cada um dos níveis. O sexo biológico foi um fator determinante para a camada a que cada sujeito pertenceria nessa polarização. $O$ órgão genital traria em si o reconhecimento social para qual andar e para qual destino sua totalidade corporal lhe levaria.

Neste sentido, à mulher, caberia a reprodução, deixando o mundo da ação e do conhecimento para os homens. Mas nem todas se reconheciam dentro desse dualismo discursivo, construído principalmente por palavras: 
O dualismo cartesiano se opõe à teoria feminista, uma vez que oposições binárias, hierarquizam e classificam os termos polarizados, privilegiando um em detrimento do outro [...] O que as feministas em geral, condenam é a associação da oposição macho/fêmea com oposição mente/ corpo, postura histórica da filosofia que trabalha com ideias e conceitos leia-se mente, termos que excluem as considerações sobre o corpo. (XAVIER, 2007, p.19)

O cartesianismo foi o grande veiculador da ideia de uma mente separada do corpo. Ao dizer a máxima "penso, logo existo", Descartes confinou a existência material ao pensamento e juntou a luz e a razão como partes indissociáveis. O logocentrismo se associou ao falo e fez o macho da espécie sentir-se dono do seu corpo e de outros corpos. Embora essa lei de domínio e poder se materializasse na submissão de corpos diferentes, era pela voz que ela se empunha, mais do que pela força. A psicanálise criou a ideia de que a mulher seria propícia à patologização da mente ao sentir a falta do falo. Embora na cultura falogocêntrica ${ }^{1}$, a mente estaria acima do corpo ou fora dele, na mulher os dois estariam intimamente ligados pela histeria ou pelo desejo manifestado. Um desejo não teorizado pelas palavras (XAVIER, 2007).

O dualismo cartesiano se desfaz quando percebemos que; para a mente existir, ela necessita de um corpo e que ela nada mais é do que a subjetividade corporificada, ou a corporalidade psíquica. $\mathrm{O}$ corpo não deixa de ser uma construção discursiva marcada pelo desejo e pelas marcas políticas, geográficas e culturais. Contudo, a diferença entre cada uma delas se dá pela corporalidade da palavra que as nomeia.

De acordo com Guberman(1999), existem diferentes corpos, todos referenciados pela linguagem e que se dividem em: corpo físico, metafísico, social, cósmico, erótico e poético. O corpo físico do autor aparece no texto de forma denotativa, mas quando transformado em signo representa uma parte do corpus da escritura. O corpo metafísico é o além do físico, traz o pensamento e a visão do outro, espírito, do enfrentamento do nada. Já o corpo social, é aquele determinado pela interação entre o sujeito e a sociedade, ou ele se integra, ou ele se marginaliza. O corpo cósmico "revelado pelo corpo individual, amplia seu universo semântico em busca de um tu coletivo, extrapolando o mundo reduzido em que se insere e cedendo espaço para o universal" (GUBERMAN, 1999 p.2 e 3). Ainda existe a definição de corpo erótico e de corpo poético, os dois se apresentam no poema, o erótico com o corpo objeto de sublimação, enquanto o poético, encarnado no próprio poema, "surge a partir do corpo físico, move-se pelo desejo de criação e presentificado pelo instante poético, transforma-se em metáfora do real imaginado, revelando se como corpus da escritura" (GUBERMAN, 1999 p.2 e3).

Em todas essas definições, quando passadas para o texto, os diferentes corpos se imbricam na escrita para formar o corpus da escritura. Expressa a dor e o desejo

1 Além do termo falocêntrico (sociedade pautada no falo), a Psicanálise Moderna também usa o termo logofalocentrismo, o qual seria mais completo, pois completaria o domínio do falo com o do logos (pensamento, razão). É um neologismo com origem na teoria da Deconstrução de Jacques Derrida e representa a primazia que o homem obteve na construção do significado das palavras. 
em forma de signo, o corpo na linguagem traz claro o corpo do sujeito que a produz, sendo o corpo deste sujeito um texto inscrito de memórias. Para Otácvio Paz, o poeta converte: "el lenguage en cuerpo. Las palabras ya no son cosas de ser signos, se animan, cobran cuerpo"(Paz,1999, p.76)². Em relação ao texto produzido por um corpo de mulher, principalmente o texto poético, apresentarei como este corpo, definido historicamente como o outro, ou o corpo excluído do discurso, se expressou ou se metamorfoseou no corpus da escritura.

A mulher na sociedade patriarcal, embora restrita aos domínios do corpo, foi alijada de sua subjetividade, ou melhor, de construir uma subjetividade própria. É como se ela tivesse um corpo com acesso negado a sua existência, a consciência de si mesmo. O corpo referenciado como o paradigma não era o dela, este não fazia parte da construção da memória, e se não habitava a memória, só poderia residir no esquecimento. O silêncio, a falta, a lacuna e a inconsciência acabaram sendo terrenos conhecidos pelas mulheres, não porque elas preferissem ou fosse- lhes natural o espaço à margem, mas porque foram reduzidas a estes. Saber se desse lugar vazio e sem nome, a mulher escritora conseguiu criar uma linguagem específica, um texto corporal único parece-me que foi o ideal de uma crítica feminista que via na valorização das diferenças, o princípio da igualdade. Uma escritura elaborada por mãos que apalpavam constantemente o silêncio só poderia vir e nascer como rasgo e como grito no vão. Os textos do corpo negado só podem operar contra o discurso.

Decidi trabalhar a relação entre corpo e texto em Cecília Meireles conhecida pela crítica pela descorporificação. Ela já morreu organicamente, isto é, teve um fim em seu corpo material. Sobraram os corpos dos seus textos. Temos aqui duas significações que se relacionam o corpo e o texto. Para Isabel Leal, "é texto tudo o que no discurso se desprende das condições normais de comunicação e significação e funciona como uma clareira, uma zona de tréguas no interior das linguagens" (LEAL, 1990, p.307). A linguagem é sempre referenciada a um corpo já que tem como objetivo o próprio ser humano.

O corpo de cada um é um texto porque somos o produto de tantos discursos construídos sobre nós "na combinação única e possível daquilo que dizem que somos, com o que julgamos ser, com o que queremos ser, com o que somos de facto (seja isso o que for). O grande signo dessa individualidade é o corpo" (LEAL, 1990 p.307). $\mathrm{O}$ sujeito tem materialidade. $\mathrm{O}$ poema também. $\mathrm{O}$ sujeito se apaga de certa maneira para o seu texto nascer. Esta seria a morte do autor teorizada por Barthes. Mas o autor não morre completamente. Seu corpo não se apaga de todo, apenas se transforma em palavra. Há uma cisão entre o corpo e o texto, ao mesmo tempo em que se descobrem mutuamente. Apaga-se o sujeito para que haja a verdadeira revelação, a que se fará pela escritura. A poesia descorporizada pode revelar aquilo que se quer apagar: o corpo, o autor, no caso aqui, a autora. Para Lúcia Castello Branco, (1994) é no apagamento do traço que o sujeito aparece. A subjetividade se

2 A linguagem em corpo. As palavras quando coisas deixam de ser signos, se animam, cobrem o corpo. 
torna uma formulação que se constrói e se desconstrói, marca-se diante do tempo e se dissolve em um simulacro de intenções. Os fios do eu.

A construção da subjetividade do sujeito passa pelo tecido da textualidade. E essa textualidade se corporifica, enquanto o corpo se textualiza. Seu sentido nasce através do discurso e é através do discurso que o sujeito ganha materialidade. Tal como uma parte da linguagem, o corpo sempre procura esquivar-se da utilidade econômica. Ele é aquilo que resta e sobrevive ao saber organizado. A realidade segmentada pelo discurso normativo. O corpo de cada sujeito é único e particular, forma-se assim a subjetividade - e este corpo se torna incomunicável. Desvelar o texto e desnudar o corpo, desvelar o corpo e desnudar o texto. Percorrer os labirintos da significação.

Cecília Meireles foi considerada exemplo de descorporificação na poesia. Chamada de etérea. Etéreo vem de éter - que significa mais leve do que o ar. Significa volátil, divino, aquilo que não se materializa. Em grande parte, a poesia desta autora foi amplamente aceita por esta aparente descorporização. Isto é, por seus textos não apresentarem à primeira vista o corpo, mais precisamente o corpo feminino. Ela foi aplaudida por trazer um texto fluído, vaporoso e sublime. Aplaudida e estereotipada ao mesmo tempo. O que era visto como virtude, também foi transformado em defeito, visto pela ótica dos movimentos de vanguardas. Mas é na ausência deste corpo que ele se faz presente. É colocando a veste e o véu que transparecem a pele e a face. A palavra costurada forma o texto e o texto como tecido costura um novo corpo.

\section{A dona contrariada}

Ela estava ali sentada, do lado que faz sol-posto, com a cabeça curvada, um véu de sombra no rosto. Suas mãos indo e voltando por sobre a tapeçaria paravam de vez em quando: e então, acabava o dia.

Seu vestido era de linho, cor da lua nas areias. seus lábios cor de vinho dormia a voz das sereias. Ela bordava, cantando. E a sua canção dizia a história que ia ficando por sobre a tapeçaria.

Veio um pássaro da altura e a sombra pousou no pano, como no mar da ventura 
a vela do desengano.

Ela parou de cantar,

desfez a sombra com a mão,

depois, seguiu a bordar

na tela a sua canção.

Vieram os ventos do oceano, roubadores de navios,

e desmancharam-lhe o pano, remexendo-lhe nos fios.

Ela pôs as mãos por cima, tudo compôs outra vez:

a canção pousou na rima,

e o bordado assim se fez.

Vieram as nuvens turvá-la.

Recomeçou de cantar.

No timbre da sua fala

havia um rumor de mar.

O sol dormia no fundo:

fez-se a voz, ele acordou.

Subiu para o alto do mundo.

E ela, cantando, bordou.

(MEIRELES, 2001, p.384 e 385)

No poema acima, a Dona Contrariada, título sugestivo que afirma uma oposição e um enfrentamento, o enfrentamento da Dona (mulher -artista), há uma narrativa contada pela poeta de uma mulher que enfrenta os mais vis tumultos e obstáculos para fazer a sua arte, bordar a sua canção, preencher com linhas a sua tela. A Dona Contrariada inicia o seu labor artístico-artesanal de cabeça curvada, a posição da cabeça feminina outorgada pela sociedade patriarcal. Devo ressaltar que curvar é diferente de baixar, embora sejam sinônimos, pois se para bordar um tecido, algumas vezes a bordadeira precisa baixar a cabeça, isso não significa que ela precisa curvar a mesma. Curvar a cabeça significa humilhar-se, dobrar-se, se o sujeito se curva, curva diante de alguém. E nem sempre para bordar, principalmente tapetes, há a necessidade de baixar a cabeça, muito menos curvar-se, o que comprova o caráter inicial de uma postura imposta à bordadeira-poeta.

Apesar da posição inicial imposta, ela persiste e trabalha, acaba o dia e ela continua tecendo o seu bordado como se tecesse um texto (semelhanças entre tecer, texto e tecido foram abordadas já no bordado da primeira parte desta tese). O preenchimento do vazio da tela se dá como da página em branco e a bordadeirapoeta não deixa nada parar o seu canto e nem o seu bordado - tela e tapete. Ela contraria todas as determinações históricas e sociais, sua cabeça curvada se torna uma estratégia para que não vejam o seu prosseguimento. Borda a sua história, canta o seu tecido e mesmo quando desmancham o seu pano (quer dizer, quando retiram as 
condições e o material para a poesia), a dona poeta contraria a todos e magicamente suas mãos fazem a canção pousar na rima, quer dizer, o texto bordado e tecido ganha asas e voa significações.

E não há maior enfrentamento do que o seu corpo de mulher e de poeta pousando no texto, sendo tecido, tanto o pano quanto o ato de tecer se tornam o instrumento do fazer poético. O rosto pode estar escondido em um véu de sombra, como foram todos os rostos de mulheres e das mulheres artistas diante de uma história contada pelos homens. Contudo, ele ainda existe por debaixo desse véu e respira, escreve e tece uma história contínua e uma arte singular por debaixo do pano permanece. Os obstáculos naturais, que a poeta-bordadeira-cantadora enfrenta e que escondem o seu rosto, enquanto desmancham a sua arte, não deixam de ser os parâmetros canônicos de uma sociedade patriarcal que decide qual rosto deve aparecer, qual história deve se contar e qual arte deve se mostrar.

Só que a sociedade patriarcal não contava com as donas contrariadas que persistem, apesar dos desmanches e dos véus, em cantar e bordar, em se criarem artistas. E se nada ainda tiverem para fazer poesia: nem panos, nem agulhas, nem tecidos e, se todos os ventos do oceano roubarem seus navios e destruírem a sua arte, elas ainda terão seus corpos como livros que, em dado momento, saltam do escuro para a história. Assim como Bárbara Heliodora, a poeta da Inconfidência, em que os esbirros da rainha rasgaram seus manuscritos. Bárbara Heliodora é tida como a primeira poeta do Brasil que se tem registro. Mulher do poeta Alvarenga Peixoto, é também vista hoje como uma das participantes da Inconfidência Mineira. Quando a conjuração foi descoberta, Alverenga pensou em delatar seus companheiros para escapar de sua sentença. Bárbara Heliodora o impediu, dizendo que mais valia a honra do que a própria vida. Depois que seu marido foi deportado para o exílio na África, a punição à sua família não terminou e a coroa portuguesa determinou que se retirasse quase todos os bens de Heliodora e seus filhos. No momento em que os soldados (esbirros) invadiram a propriedade do casal para a sentença derradeira, conta-se que os mesmos encontraram os cadernos de poesia de Bárbara, rasgando-os imediatamente. Esse ato (rasgar os escritos de uma mulher) se transfigura de muito simbolismo sobre o lugar do texto de autoria feminina em uma sociedade patriarcal, cabendo à mulher apenas o silêncio e o apagamento.

Neste sentido, de apagamento e silenciamento que a história as confinou, as poetas, as artistas, as mulheres ainda terão o seu corpo para inscrever ao seu canto: "Seu vestido era de linho,/cor da lua nas areias. /seus lábios cor de vinho/ dormia a voz das sereias [...] Ela pôs a mão por cima/ tudo recompôs outra vez [...] Vieram as nuvens turvá-la/ Recomeçou a cantar/ No timbre de sua fala/ havia um rumor de mar". E o que é a nuvem para turvar o seu corpo, quando a sua voz tem o rumor do mar? Seu corpo é seu texto, funde-se com ele, borda na pele a sua história e canta o seu destino. E não há nada que possa desviar a poeta dele, nem o patriarcado. Quando o sujeito que tece o texto é uma mulher, todas as agulhas-canetas são instrumentos de uma nova consciência: 
[...] la lucha que libran algunas muyeres que escriben (..) por plasmar la palavra que las espresen - esto es, su cuerpo, sus vivencias, su sentir que expresse, al mismo tempo, al mundo y que les permita, ademas dar testimonio de su próprio processo y consciência de escritoras (GONZALEZ, 1990 p.26)³

A descorporificação esconde a corporificação. A negação é apenas aparente. Ela afirma o lado que estava obscuro. Aqui, o corpo no discurso. O corpo feminino parece circundar a morte, a não afirmação. Henriqueta Lisboa, poeta contemporânea à Cecília, em uma entrevista a Edla Van Steen (1982), afirma que o tema da morte é um "assunto infinitamente sugestivo, aberto a todas as hipóteses e voos imaginários" e que "nenhum poeta de maior seriedade deixou de lado esse tema". É como se a escrita de autoria feminina procurasse a própria essência do ser, o mistério poético e a revelação do inefável, na busca pela infinitude. $\mathrm{O}$ desejo de permanecer além do tempo. A morte é a limitação e a finitude do corpo. O que vai sobrando são os elementos - figuras da luta sem trégua com a escrita. Cada poeta mulher aqui travou a sua - rasgando as palavras de sua referencialidade. Restou um nome. Restou "la palabra escuchada, cifrada, dicha y escrita desde el cuerpo, desde el propio ser de mujer, como la única posibilidade de transcendencia senal del espíritu" (PRADO, 1990, p.27)4

Cecília Meireles é etérea, porque queriam encontrar com a luz na voz da sombra. A luta com as palavras é árdua, é preciso levitar-se. Sobrepor com o texto, o corpo. Como diz Cecília Meireles a Henriqueta Lisboa em uma carta de 24 de setembro de 1947: "Sabemos tão bem como as palavras são impossíveis para comunicar o que elas nos trazem no seu mistério que eu sei que V. me perdoará dizer lhe apenas minha melancólica surpresa." (Manuscrito, Arquivo de Escritores Mineiros, Acervo de Henriqueta Lisboa, maio de 2015)

A melancolia é a arte de procurar esse corpo na eteriedade. Melancoliza-se porque a falta não se preenche, o corpo não se encaixa na sombra, e as palavras já não dizem. Materializam-se as imagens agora. E é isso que podemos notar nas tecituras dos textos de Cecília Meireles. É impossível negar que houve um corpo que os houvesse gerado. E que este deixou seu rastro nas figuras semânticas criadas, pois, a mulher que escreve sofre uma angústia semelhante ao ato de gestar e parir: "El processo de la escritura es su proprio proceso físico, fisiológico, ético, intelectual, es una palabra vital. La historia se da a luz desde la escritura" (GONZALEZ, 1990, p.28)5. Nesse sentido, a mulher escreve como se parisse, o processo de criação se gesta. E não só às mulheres poetas, mas também para muitos escritores, a criação artística é gestar. É possuir um útero imaginário.

\footnotetext{
3 A luta que defende algumas mulheres que escrevem por modelar a palavra que as expressem - esta é, seu corpo, suas vivências, seu sentir que expresse, ao mesmo tempo, o mundo e que as permita, ademais dar o testemunho de seu próprio processo e consciência de escritoras.(tradução de minha autoria).

4 A palavra escutada, cifrada, dita e escrita pelo corpo, pelo o próprio ser da mulher, como a única possibilidade de transcendência sinalizada pelo espírito. (tradução de minha autoria).

$5 \mathrm{O}$ processo da escritura em seu próprio processo físico, fisiológico, ético e intelectual, é uma palavra vital. A história se dá a luz a partir da escritura. ( tradução de minha autoria).
} 
Fala-se na descorporificação da poesia de Meireles, mas não se menciona que se descorporifica o que já existe. Se há falta do corpo, é porque em algum momento esse corpo existia, é porque em algum lugar esse corpo se esconde. Mesmo que dele só reste uma voz que irá se confundir com a luz ou se guardar na sombra. A fala é plena, é presença. O discurso parte do eu e esse eu se constrói junto com o seu corpo. A voz vira vestígio da matéria que se transforma em palavra: "Haja luz; e houve luz" (BÍLIA SAGRADA, Gênesis, capítulo 1 vers.3) "No princípio era o Verbo, e o Verbo se fez carne" ( BÍBLIA SAGRADA, João, capítulo 1 vers.1).

Contudo, a fala apesar de presença é perene. Ela se desmancha com a luz. Seu corpo se dissolve por meio às sombras. A escrita parece vencer a porosidade, parece materializar a voz. Ela ainda é capaz de vencer o próprio corpo. Vence o corpo único e particular, não só de quem a cria, mas também de quem a recria no processo de leitura. A construção da escrita passa antes então pela construção de si: "a construção de si opera-se antes de tudo pela sexualidade- e mais amplamente pelo corpo. É pelo corpo, e principalmente o corpo que deseja, mas que também é ameaçado que o retorno a si vence as aventuras do mundo". (TOURAINE, 2004, p. 56).

O espaço da sexualidade não se restringe apenas ao organismo, ela é o espaço do desejo, e este vai além de sua vivência física. A dinâmica do desejo comporta a dimensão discursiva. O discurso se cruza com outros discursos, mas também com outros corpos. Há um duplo processo de elaboração de enunciados e formas, neste entrelaçamento de textos e corpos, que se nomeia de intertextualidade. Para Guberman (1999), não se pode pensar em estudar o corpo na poesia, apenas o relacionando com a sexualidade, mas também deve se entender como funciona o desejo. O desejo é a ação do querer apropriar-se do outro. Escrever é tentar essa apropriação através das palavras. Corporiza-se em palavras. E se essa corporização tiver um sexo, um gênero? As palavras não têm sexo, dirão. Mas e quando um poeta como Octávio Paz diz: "o poeta é "homem de desejos" (PAZ, 2012 p.73)? O desejo, visto como responsável pelo ato da criação poética, seria apenas uma emoção do homem? E somente o homem, por ter desejo, seria capaz de criar a poesia?

Uma indagação como essa, deixa implícita a ideia de que o poeta é homem e não mulher. Uma afirmação dita em um ato falho, afinal, diria o patriarcado, homem seria a expressão de humano, quase que um nome neutro para simbolizar os dois. Contudo, foram as teorias de gênero que identificaram que, por trás da suposta neutralidade da palavra homem, existe o próprio patriarcado afirmando que o ser humano considerado completo, inclusive modelo de corpo e de mente, é o do sexo masculino. A mulher seria um ser humano incompleto, menor e deficiente. Seu corpo visto como erro da natureza. Nesse sentido, a mulher que escreve seria um desvio duplo da natureza, pois como humano incompleto não teria desejo, indispensável para a criação poética. Na verdade, as mulheres aprenderam a negar seus desejos durante a história. Desta maneira, a poesia nascida de mãos femininas não emerge sem antes enfrentar a negação do desejo. Ela é o fruto do enfrentamento dessa negação que vira afirmação. Paz continua: 
De fato, a poesia é desejo. Mas esse desejo não está vinculado ao possível nem ao verossímil. A imagem não é o "impossível inverossímil", desejo de impossíveis: a poesia é fome de realidade. O desejo aspira sempre a suprimir as distâncias, como se vê no desejo por excelência: o impulso amoroso. A imagem é a ponte que o desejo constrói entre o homem e a realidade. $\mathrm{O}$ mundo do "oxalá" é o mundo da imagem por comparação de semelhanças, e o seu principal veículo é a palavra "como" isto é aquilo. Nela o desejo entra em ação: não compara nem mostra semelhanças, mas revela - e mais: provoca - a identidade última de objetos que nos pareciam irredutíveis. (PAZ, 2012, p.73)

A linguagem representa as vestes de um texto coletivo, fruto do pensamento de uma sociedade. Percebo que o corpo se metamorfoseia em palavras, sua significação explode em gestos que revelam poemas. Há uma lógica natural na construção desse corpo, principalmente se mulher, mas que perpassa toda uma história de apagamento, exclusão e silêncio. A poesia gerada por esse corpo não pode ser igual àquela gerada por um corpo presentificado, historiografado, estudado e tido como referência. O corpo feminino é descorporificado constantemente por essa civilização centrada no falo. Por essa razão, escrever sendo mulher é um constante desapagar, fazer a luz e iluminar os traços e os contornos silenciados. E em seguida, apagar de novo, descorporifica-se.

De acordo com Corbin (2009) acreditava-se há mais de mil anos, que os orgãos sexuais femininos tinham uma estrutura igual aos masculinos, ou seja, a mulher por dentro, teria um corpo de homem. Segundo ainda esse pesquisador da história do corpo, Aristóteles acreditava que a mulher era um vaso, um receptáculo vazio, no qual o homem depositava a sua semente (CORBIN, 2009, p.185). Já Hipócrates, considerava o orgasmo feminino indispensável para a criação de uma nova vida. Haveria uma ordem cósmica na liberação dos fluídos femininos e masculinos em comunhão para gerar outro corpo, outro ser: "Assim se estabelecia, naturalmente, uma relação lógica entre o prazer e a fertilidade, entre a frigidez e a esterilidade" (CORBIN, 2009, p.186).

A visão hipocratiana do corpo feminino e de suas funções reprodutivas não sobreveviveu à Idade Média e nem ao Renascimento, pois a Ciência desmistificou essa ligação entre prazer e concepção. $\mathrm{O}$ corpo feminino torna-se um perigo e a reprodução aconteceria independente do desejo e das ações das mulheres:

O conjunto das relações estabelecidas entre os homens e mulheres se encontram, a partir disso, redefinidas. Os partidários da subordinação a mulher recorrem à biologia. Jean Jacques Rousseau, no quinto livro de Emílio, havia apontado as diferenças, consideradas naturais, que distinguiam os dois sexos. O macho, ativo e forte, é macho em certos momentos. A mulher é mulher a cada instante de sua vida. Tudo, nela, evoca o seu sexo. Portanto, 
é necessário garantir-lhe uma educação particular. A crença segundo a qual os avanços da civilização acentuam a diferença entre o homem e a mulher embasa solidamente a divergências dos papéis. Esta divisão, acredita-se, deve ordenar todas as relações sociais, sobremaneira o discurso e o jogo amoroso. A mulher descobre o desejo quando focaliza seus sentimentos sobre um indivíduo $\mathrm{O}$ homem pode ser invadido por uma necessidade de mulher que uma parceira casual poderá satisfazer. Essa diferença radical nas modalidades do desejo fundamenta o duplo padrão da moral. (CORBIN, 2009, p.187)

Corbin analisa neste trecho, de que forma a Ciência está imbricada com a ideologia de que o corpo feminino era feito para a reprodução. Toda pouca literatura médica que se fará tendo o corpo da mulher como objeto de estudo é para justificar o destino e a submissão das mulheres ao casamento, ao marido e aos filhos. Seu corpo seria uma construção da natureza para reproduzir outros corpos e não para criar. Se até a criação da vida em seu ventre seria obra da semente do homem, imagine a produção de seus textos. Seu corpo - uma fábrica como disse Jorge de Lima em seu poema Mulher Proletária: "Mulher proletária - única fábrica/que o operário tem, (fábrica de filhos)" (LIMA, 2003 p.286 e 287).

Se seu corpo só serviria à reprodução e seu desejo deveria se focar em um homem só, as mulheres que ousassem escrever poesias, que não fossem reproduções de metáforas e versos do senso comum e que, na vida pessoal, não casassem ou casassem mais de uma vez, estariam fugindo das regras e subvertendo seus corpos e seus textos. Cecília Meireles escapou à lógica reprodutiva e amorosa a que estava fadada o corpo da mulher e o texto da mulher, pois ela casou duas vezes, assim como escreveu poesias em um grande exercício de criação, não reproduzindo as mesmices literárias destinadas às poetisas. Denominamos aqui de poetisas as mulheres que escreviam versos dentro dos parâmetros patriarcais de como deveria ser uma poesia feita por mulher, geralmente são àquelas que participavam de salões, saraus e datas comemorativas com versos comedidos e de figuras doces e vistas como femininas. Diferente da poeta, a que escrevia para ultrapassar estereótipos determinados ao seu gênero e à sua escrita para fazer literatura. Para isso, deve escrever com todo o seu corpo de mulher real e não com o corpo de mulher moldado pelos homens.

Ela escrevia como se parisse, mas não de acordo com a concepção do homem de gestar e parir, engendrada por tantos séculos na literatura, na ciência e na sociedade. Parir o texto aqui é resgatar a autonomia criativa e o papel ativo da mulher em todos os campos da vida. É criar como faziam as deusas. Talvez por isso que ela não se subordinou às escolas e aos modismos literários de filiação masculina como o Modernismo. Pois, a mulher que escreve não quer ser mero vaso ou receptáculo vazio para a semente textual do homem, seus textos são frutos de suas mãos e de suas respirações. Há um desejo claro da autora de não aderir passivamente à simples reprodução de ideias ou formas textuais criadas por um movimento quase todo 
masculino. O que querem as escritoras, é mostrar na literatura e na vida que elas são donas de seus corpos e que seus textos são frutos de seus corpos, por isso lhes pertencem. Como bem disse Mário de Andrade sobre Cecília Meireles:

Eu acuso Cecília Meireles de várias culpas contra a poesia. E nem me parece duvidoso que a maior destas culpas seja ela ter se candidato a um prêmio da Acadêmia. Que estranha, volúpia, muito feminina, de perder, a teria levado a essa aventura?... E disso lhe aconteceu outra culpa, não menor, a de conquistar o prêmio![...] Cecília Meireles terá querido ternamente elevar a coletividade acadêmica se sacrificando a si-mesma em ser premiada pela Academia. E eis nos diante da madrigalesca lição da maior sinuca literária destes últimos meses: a academia acaba de ser premiada por ter concedido um prêmio à poetisa Cecília Meireles. (ANDRADE,1955). ${ }^{6}$

A poeta carioca teria se excluído do Modernismo por opção própria. Ela não se via contemplada naquele movimento, sua concepção estética e seus valores espirituais e por que não, corporais não se encaixavam nas novas regras. Sim, porque um estigma de sua poesia é o de que esta seria descorpórea, fluida, perene. Há aqui uma clara percepção de sujeito que embasa esse julgamento, e que; privilegia uma ideia de corpo linear, único, um território estável do sujeito e de gênero masculino por excelência. Um corpo que tenha domínio de todas as suas sensações e sentimentos e com uma mente que comanda (CORBIN, 2005). Quando se afirma que Meireles é descorpórea, pergunto qual a concepção de corpo que embasa essa afirmação. Não é a mesma que está em seus poemas, a qual não é a concepção de corpo do patriarcado.

De acordo com Ana Pizarro (2005), no momento político em que viviam nossas três autoras no Brasil, o governo ditatorial de Vargas pregava a moral "Lar, Escola e Pátria” com muita veemência, sendo estes três lemas a base do regime autoritário. Esse regime necessitava de uma a mulher sem sexualidade, sem corpo para poder impor o autoritarismo dentro da família. A intensa repressão que vem do Estado traz consigo o reforço de que as famílias precisam ser monogâmicas e religiosas e

6 Este texto de Mário de Andrade inserido no livro O empalhador de Passarinho, mostra bem como a crítica masculina se comportava na época diante da ousadia, não só da existência de um texto escrito por uma mulher, mas desta mulher disputar com esse texto os espaços públicos literários vistos como propriedades do homem. O que se subtende no texto de Andrade é que, não bastasse a poeta escrever, ainda cometia o enfrentamento de galgar reconhecimento e espaço dentro de um território tido como masculino, como é o caso da Academia. Lógico que ele como um bom crítico conserta esse espanto inicial ao dizer que era Cecília que premiava a Academia, e não ao contrário. No final de sua análise, Andrade constrói uma visão sobre a poesia de Meireles que pode ser prepoderante para o entendimento estereotipado que sua poesia ganhou entre os críticos homens, isto é, de uma poesia ligada ao sentimento e às emoções, trecho o qual eu transcrevo: "E assim, pude retirar do poema de Cecília Meireles o meu poema, a minha intuição, o que para mim foi uma definição nova de certo momento irracional que eu já observara, mas ainda não sentira, não conhecera poéticamente no seu poder de comparação, de experiência, de simbologia. Sentimento profundo, definição reveladora que só pude obter pela graça da poesia. E pela força criadora de Cecília Meireles". 
a mulher seria o sujeito a fazer esses valores vingarem, sem a mulher não haveria moral. Pizarro cita Gilberto Vasconcelos que afirma que no período Varguista:

[...] o corpo é desvalorizado, os sentidos a parte mais degradante do homem. A espiritualização do corpo e do amor constitui a contrapartida do ódio à sexualidade. A isso se entrelaça a misoginia de fundo patriarcal [...] A apologia reacionária da mãe, sua descarnalização tem como função converte-la no suporte da família autoritária, a qual é inimaginável sem sua dessexualização e da criança. (VASCONCELOS apud PIZARRO, 2005 p.34)

Se os valores impostos por um governo autoritário estavam ligados diretamente à descorporificação da mulher e, em contrapartida, a sua profunda espiritualização, é de imaginar que esses valores tenham contaminado a recepção crítica das obras escritas por mulheres, na medida em que esses seriam os valores procurados em seus textos. A espiritualização da poesia ceciliana se inicia na ânsia social, consciente e inconsciente, de procurar no texto escrito da considerada maior poeta brasileira, os valores que satisfizessem a imagem da mulher ideal do período. Sua poesia deveria ser espiritualizada, descorpórea, desencarnada e sem sexualidade para se converter em uma poesia feita por uma mulher perfeita e completa (como disse Mário de Andrade sobre Cecília e Gabriela Mistral).

Lendo Viagem, por exemplo, que a autora carioca considera sua primeira grande obra, vejo o corpo, presente o tempo todo na tecitura de seus versos. Mas um corpo desregrado, desencaixado, aberto e espontâneo, onde as sensações são proeminentes. Como no poema Excursão, um dos primeiros poemas de Viagem, no qual os olhos, nariz, boca se misturam e seus sentidos se integram à paisagem: "Estou vendo aquele caminho/cheiroso da madrugada/pelos muros escorriam/flores moles da orvalhada/ na cor do céu, muito fina/ via-se a noite acabada" (MEIRELES, 2001, p.230). O corpo é metonímico. O caminho se cheira, a flores escorrem pelo muro ou será o muro que escorre com as flores?

Esse não encaixe de Cecília aos preceitos do Modernismo foi tomado por uma boa parte da crítica como uma prova de sua inadequação ao espaço e tempo, como se ela estivesse fora das discussões sobre a renovação estética que se promulgava, como cita Ana Cristina Cesar (1993) em seu livro: Escritos no Rio. Neste livro, Cesar faz uma análise da poesia de Meireles tendo em vista, a revolução na linguagem e na forma literária que o Modernismo propôs. Ela conclui que Cecília escreveu uma poesia tradicional na forma e pouco ousada na linguagem, repetindo estereótipos imagéticos ligados à mulher como a nuvem, a flor e o jardim. Contudo, Ana Cristina César não leva em consideração a capacidade que teve Cecília de renovar esse mesmo quadro imagético, transpondo do comum para o indizível e colocando o corpo feminino em transfiguração na natureza.

Neste sentido, dificilmente a crítica falogocêntrica pensaria em analisar o corpo na obra da poeta carioca, pois a imagem de poeta efêmera e espiritualizada 
já ganhou proporções difíceis de contornar. Porém, algumas vezes ele aparecia como na leitura filosófica de Ruth Cavelieri (1984), para a qual o corpo tem o papel preponderante na elaboração de imagens. A corporificação das metáforas é uma forma de despertar o sensual concreto dessas imagens, na qual se entrelaçam para dar a medida do poema. Revelar o corpo sutilmente em partes para que possa assim, não apenas encontrar a unidade, mas lutar contra o desregramento do tempo, "livrar o corpo da lição da areia" (MEIRELES). Segundo CAVALIERI (1984), Cecília "opera com o corpo como opera com o tempo, desintegra para unir; reduz para conduzir a microcospia do ser" (CAVALIERI, 1984 p.6o). Igual a estes trechos do poema Mar Absoluto, no qual une a transfiguração do corpo na natureza, com a temática da solidão mais profunda do ser encarnada na figura do mar:

\section{Mar Absoluto}

Foi desde sempre o mar

E multidões passavam e empurravam

como um barco esquecido

Agora recordo que falavam

da revolta dos ventos,

de linhos, de cordas, de ferros

de sereias dadas as costa.

E o rosto de meus avós estava caído pelos mares do Oriente, com seus corais e pérolas, e pelos mares do Norte, duros de gelo.

[...]

E fico tonta.

acordada de repente nas praias tumultuosas.

E apressam-me, e não me deixam sequer mirar a rosa dos ventos.

"Para adiante! Pelo mar largo!

Livrando o corpo da lição da areia!

Ao mar! - Disciplina humana para a empresa da vida!"

Meu sangue entende-se com essas vozes poderosas.

A solidez da terra, monótona

Parece-nos fraca ilusão.

Queremos a ilusão grande do mar.

Multiplicada em suas malhas de perigo.

(MEIRELES, 2001 p.448 e 449)

No poema Mar Absoluto, o mar é reverenciado como um grande ser que regula a vida e os corpos de todos que dele dependem. Ele representa um grande Deus que exerce o poder de vida e de morte sobre todos os seres em volta como era a Grande Deusa Mãe no matriarcado. São seres maiores, atemporais porque sobrevivem a 
todos os ventos do tempo e, em sua infinitude de tamanho e de idade, mostram como os seres a sua volta são pequenos e finitos. A relação aqui é de corpos, o corpo imenso do mar em contraste com os corpos pequenos que dele dependem, eles são "as multidões com seus barcos esquecidos" (MEIRELES, 2001). O mar guarda os segredos, as histórias, ele é o presente e o passado e nesse instante, aparece o corpo lírico recordando e legitimando o poder que dos oceanos emana.

Recordar tem o significado de trazer a tona, vir à memória (HOLANDA, 1986), ou seja, emergir do fundo para cima, trazer o que estava escondido para a superfície. Assim faz também o mar, reino da melancolia, escondendo e revelando histórias, segredos e corpos. A poeta recorda, isto é, emerge destes mares os rostos de seus avós que simbolizam heranças culturais, e o passado tornado o presente. Segundo Cavalieri, o rosto unifica os fragmentos corporais, algo constante na poesia de Cecilia em que transbordam as imagens de olhos, boca, lábios, mãos e sensações como cheiro, imagem, sons para que possa se fundir à natureza: "o rosto se destaca como metáfora de um núcleo de recomposição” (CAVALIERI, 1984 p. 6o). O mar integra por excelência, ele liga um polo a outro e todos os continentes, devolve para os fragmentos de terra "a solidez da terra monótona" a noção de que fazem parte de um mesmo corpo - planeta. Ele reconstrói os rostos de seus avós, a face de seu passado, faz o seu sangue, corpo submerso da pele, encontrar-se com as vozes mais profundas que esse mar entoa do passado ao presente, da história ao eterno, do fundo à superfície, do sonho à realidade, de dentro para fora, do vazio para a plenitude, do espírito para o corpo e da vida para morte. Resta a solidão, mar absoluto de todos os seres.

Neste sentido, será a natureza a unificadora do corpo fragmentado, em pedaços, na poesia ceciliana. No poema Mar Absoluto essa unificação se materializa na figura do mar, ou o vento e os pássaros no texto da Dona Contrariada que mesmo estes seres desmanchando o tecido - o corpo de pano, obrigam as mãos da poeta, trazer todo o seu corpo para dentro da costura do texto para que este se construa como um todo.

O mar é uma figura constante na poética ceciliana. Ele e infinito e senhor do planeta ao mesmo tempo, útero da vida, líquido amniótico, ser imenso que paira além das ondas e do céu. Por isso, nada mais certo do que chamá-lo de mar absoluto e que de alguma forma se liga ao corpo feminino, quando reverenciado como um lugar da origem da vida comparado com a água primordial em que um bebê se envolve dentro da mãe. $O$ mar é masculino em português, mas não se deve esquecer que em outras línguas como o francês, ele é feminino: mer, palavra que se pronuncia nesta língua igual a mãe - mère.

O mar que é a mãe, a mãe que é o mar, envolve com poder todas as coisas iniciais e ancestrais, tanto da história humana, quanto da história do planeta. Àquelas que não se nomeiam e que não se escrevem. A poeta celebra neste poema um corpo uno, maior que a extensão entre sua mão e a escrita, um corpo absoluto, imenso e redondo igual aos oceanos cobrindo toda extensão do corpo da Terra. O corpo que se costura aqui é aquele que pare como o mar pariu as primeiras formas de vida. 
Absoluto em unir histórias, vidas, seres e desejos. É como se esse poema pedisse que o limite da forma (aquele que determina a diferenciação do corpo) fosse abolido em prol de uma intensa reconfiguração das polaridades, onde o feminino e o masculino se completam em uma extensa andrógina linguagem poética. Cecília Meireles tece seus poemas em plena corporeidade imagética, dona contrariada pelos plenos mares absolutos de sua poesia.

\section{Referências Bibliográficas}

ANDRADE, Mário. Cecília e a poesia. in: $\mathbf{O}$ empalhador de passarinho. $2^{\circ}$ edição São Paulo: Martins, 1955.

ANDRADE, Mário. Viagem. in: $\mathbf{O}$ empalhador de passarinho. $2^{\circ}$ edição São Paulo: Martins, 1955 .

BÍBLIA SAGRADA. Traduzida por João Ferreira de Almeida. zed. Barueri: Sociedade Bíblica do Brasil, 2008.1536 p.

CASTello BRANCO, Lúcia. A Traição de Penélope. São Paulo: Annablume, 1994.

CAVALIERI, Ruth Vilela. Cecília Meireles: O ser e o tempo na Imagem Refletida. Rio de Janeiro: Achiamé, 1984.

CORBIN, Alain. História do Corpo: Da revolução à Grande Guerra. Trad.Jaime Clasen. Petrópolis: Vozes, 2005.

GONZALEZ, Gralia Lopez. Dos tendências em la Evolución de la Narrativa Contemporanea de Escritoras Mexicana. In: GONZALEZ, Arália. Mujer y Literatura Mexicana y Chicana Culturas em contacto. Tijuana: El Colegio de México, 1990.

GUBERMAN, Mariluci. O corpo na poesia hispano americana de vanguarda. Londrina: Editora Uel, 1999.

HOLLANDA, Heloísa Buarque. Tendências e Inpasses: o feminismo como crítica da cultura. Rio de Janeiro: Racco, 1994.

LEAL, Isabel. O corpo como texto e como discurso in: Análise Psicológica, 3 (VIII)1990: 307-310. http://www.isabel-leal.com/portals/1/pdfs/1990_3_307.pdf, acesso em 13/11/2016. 
MEIRELES, Cecília. Carta à Henriqueta Lisboa. Rio de Janeiro, 24 de setembro de 1947. Carta manuscrita localizada em Belo Horizonte no Arquivo de Escritores Mineiros, UFMG.

MEIRELES, Cecília. Poesia Completa I. Rio de Janeiro: Nova Fronteira, 2001.

PAZ, Octávio. O arco e a lira. Trad. Ari Roitman e Paulina Wacht. São Paulo: Cosac Naify,2012.

PRADO, Gloria. La Lucha sin trégua em la escritura de algunas mujeres in: GONZALEZ, Arália. Mujer y Literatura Mexicana y Chicana Culturas em contacto. Tijuana: El Colegio de México, 1990.

PIZARRO, Ana. Gabriela Mistral el proyecto de Lucila. Santiago: LOM Ediciones, 2005 .

STEEN, Edla Van. Entrevista com Henriqueta Lisboa. São Paulo: Acervo de Escritores Mineiros, Manuscrito, 5 de maio de 1982.

TOURAINE, Alain. O mundo das mulheres. Trad. De Franscisco Morais. Petrópolis, Vozes, 2004.

XAVIER, Elódia. Que Corpoé Esse? O corpo noimagináriofeminino. Florianópolis: Mulheres, 2007. 